\title{
DIGITAL AND SEMIOTIC MECHANISMS OF CONTEMPORARY POPULISMS (PART 1) - A PRESENTATION
}

\section{MECANISMOS DIGITAIS E SEMIÓTICOS DOS POPULISMOS CONTEMPORÂNEOS (PARTE 1) - UMA APRESENTAÇÃO}

\section{Daniel do Nascimento e Silva ${ }^{* *}$}

This Special Issue of Trabalhos em Linguística Aplicada, a journal in the field of applied language studies, gathers contributions from the fields of language studies, anthropology and communication studies, all invested in understanding the current state of politics in different societies brought about by transformations in communication infrastructures, forms of governance, and modes of disciplining subjects and language. This is the first of two instalments devoted to populisms; here are ten papers written either in English or Spanish. Another instalment with articles in Portuguese is in the making.

In this issue, authors address political transformations in different parts of the world: Sara Roberts discusses the rising symbolic violence and xenophobia embedded in the British referendum to leave the European Union, famously branded as BREXIT; Ico Maly studies the sociotechnical assemblage of digital media, algorithmics, politicians, journalists, users and other actors in the production of the algorithmic populism of the extreme-rightwing party Flemish Interest in Belgium; Piia Varis looks at Donald Trump's Twitter-based populism, thus addressing a major emanation of populist textuality, style, ideology, and politics; Juan Eduardo Bonnin gauges the possibility of a populism without a leader in the algorithmic activism of Chilean protesters, who organized the protests that have shaken the country and the world; Paulo Damian Aniceto addresses an emerging facet of contemporary states - punitivism and the consolidation of the penal state - by analyzing discourses

\footnotetext{
* Programa de Pós-Graduação em Linguística, Universidade Federal de Santa Catarina.

** Programa Interdisciplinar de Pós-Graduação em Linguística Aplicada, Universidade Federal do Rio de Janeiro. dnsfortal@gmail.com

Orcid: http://orcid.org/0000-0002-6098-5185
} 
in a youth detention facility in Argentina; Leticia Cesarino, Ana Paula El-Jaick, and Daniel Silva single out different aspects of the growing right-wing radicalization of Brazil's Bolsonaro - while Cesarino proposes a comparative analysis between the Brazilian case and the populism of Narendra Modi in India (and Turner's classic study on liminality in the Ndembo of Zambia), El-Jaick and Silva single out Brazil itself, particularly its executive leader's extrapolations of the unsayable and his reactionary populism. Other two studies - Jan Blommaert's and Vinicius Vargas Vieira dos Santos' - are not necessarily devoted to addressing the political situation of particular countries; they instead look at how political discourse, interaction, and uptake have been completely reshaped by the offline-online nexus on which we carry out our daily lives and shape our political sensibilities, as Blommaert pioneeringly proposed.

In his influential epistemic appraisal, Luiz Paulo da Moita Lopes (2006, p. 14) wrote that a good definition of Applied Linguistics is that this is a field interested in "creating intelligibility about social problems in which language plays a major part". I had no other objective in mind when I proposed this special issue to Viviane Veras, the journal's editor in chief. She and I shared the belief that the resources of a top tier journal in Applied Linguistics in Brazil, hosted in a rigorous and innovative collection of open-access journals like Scielo, could be marshalled to the end of inviting scholars to create intelligibility about the disjunctions in the current world. In the past ten years, major transformations have affected democracies around the world: the United States went from being represented by a Nobel Peace Prize laureate to a billionaire celebrity who says he can push the atomic bomb button at any time; the United Kingdom left a major multilateral economic and political bloc for the uncertainty of a redefined, bounded (and supposedly more homogenous and sovereign) polity; Brazil is slowly abandoning the democratic accomplishments of its young three-decade democracy and plunging into the military past it had refused to address.

While this short list of novelties and puzzlements concerns us as citizens, our current predicaments also point to important research problems, and we are here to respond to them as scholars. Studies in sociolinguistics, pragmatics, applied linguistics, anthropology and other fields have been calling attention to the fact the anxieties I have mentioned above - as well as the current transformations of globalization - are increasingly being affected by digitalization. Digital technologies of communication are much more than "enablers of the interactivity and mobility of people"; they alter "the very nature of this interactivity, transforming the sense of place, belonging, and social relations" (JACQUEMET, 2019, p. 153). 
Research on emerging forms of populisms in the world has indicated that electoral campaigns and current governments are recycling regularities of interaction in digital networks (e.g., the possibility of interacting with a digital influencer in a "non-mediated" fashion, as Cesarino and Silva discuss in this issue) and embedding them in neoliberal patterns (e.g., the deregulation of social security and labor, punitivism, millenarianism), in such ways that politics, the social welfare state, and democratic institutions themselves are redefined. Currently, attacks on state institutions, science, environment, and the rule of law are systematic. In Brazil, as Leticia Cesarino (2019) argues, the regularities in producing semiotic patterns in WhatsApp and other digital media and disseminating them across different publics are part of a "science of populism", that is, a planned process of digitally producing the figure of the "people", embodied by a charismatic leader who is opposed to an "enemy" (see LACLAU, 2005, and MOUFFE, 2019). The popularity of Jair Bolsonaro largely relies on this digital mechanism.

As most studies in this special issue demonstrate, Brazilian digital populism is not unique. Drawing from the algorithmic and communicative affordances of different platforms, Ico Maly (2018, and this issue) proposes the notion of "algorithmic populism", whereby populism is understood not as an ideology but as a communicative relation. Blommaert's article in this issue neatly unpacks the major characteristics of contemporary communicative relations in the field of politics: they no longer follow the linear imagination of Saussure's speech circuit or Habermas' public sphere but rather use polycentric, niched, and algorithmically oriented networks. Contemporary populist movements have thus built on the reconfigurations of their audiences (BLOMMAERT, this issue), the affordances of the media (CESARINO, this issue; BONNIN, this issue; SANTOS, this issue), and the notion of "truth" (VARIS, this issue; SILVA, this issue) in the contemporary world. Populisms have also capitalized on meta-messages (or language ideologies): Piia Varis, in this issue, shows that Trump spends a great deal of his time carving this reflexive layer, with the mediatized success we know, and Ana Paula El-Jaick and myself point to how Bolsonaro often crosses the borders of rationalizations of language by saying the unsayable, and by bringing abjection into the domain of everyday objects. Thus, contemporary populisms also capitalize on symbolic (and empirical) violence - something Sara Roberts addresses in depth in this issue. Contemporary populisms also morph and build on existing patterns of neoliberal governance, such as the punishing of the poor, as Aniceto discusses in his article.

In line with Moita Lopes' pioneering stance, I do hope that the contributions to this issue of Trabalhos em Linguistica Aplicada help produce intelligibilities about 
the current digital and semiotic transformations of global politics, in general, and populisms in particular. To bring this presentation to a close, I should stress that I would not have been able to mount this collection of articles without the aid of colleagues who acted either as interlocutors in the general project or as peerreviewers. Thus, I am grateful for the fundamental input from and interlocution with: Viviane Veras, Ana Cecilia Bizon, Tereza Maher, Cynthia Agra de Brito Neves, Érica Lima, Joel Windle, Marco Jacquemet, Dawn Cunningham, Joana Plaza Pinto, Luiz Paulo da Moita Lopes, Branca Fabricio, Claudiana Alencar, Daniela Palma, and Junot Maia. I also thank Esmeraldo Armando Santos, from the Setor de Publicações (Publication Sector) at the IEL/Unicamp, for his brilliant editorial advice and formatting.

\section{REFERENCES}

CESARINO, Leticia. (2019) On Digital Populism in Brazil. PoLAR: Political and Legal Antbropology Review. Available at: https://polarjournal.org/2019/04/15/on-jairbolsonaros-digital-populism/

JACQUEMET, Marco. (2019) The Digitalization of the Asylum Process (and the Digitizing of Evidence). In: Hass, Bridget \& Amy Shuman (Eds.) Technologies of Suspicion and the Ethics of Obligation in Political Asylum. Athens: Ohio University Press.

LACLAU, Ernesto. (2005). On populist reason. Londres: Verso.

MALY, Ico. (2018) Algorithmic populism and algorithmic activism. Diggit Magazine. Available at: https://www.diggitmagazine.com/articles/algorithmic-populism-activism

MOITA LOPES, Luiz Paulo. (2006) Por uma Linguística Aplicada Indisciplinar. São Paulo: Parábola

MOUFFE, Chantal. (2018) For a left populism. Londres: Verso.

Recebido: $10 / 04 / 2020$

Aceito: 10/04/2020

Publicado: 13/04/2020 
